\title{
Effect of stage of cycle, sampling frequency and recovery of micro-organisms on total protein content of mare uterine flushings
}

\author{
P. J. Strzemienski and R. M. Kenney \\ University of Pennsylvania, School of Veterinary Medicine, Section of Reproductive Studies, \\ New Bolton Center, Kennett Square, PA 19348, U.S.A.
}

\begin{abstract}
Summary. Mares with sound reproductive tracts were divided into two groups. In Group I $(\mathbf{N}=12)$, uteri were flushed once per oestrous cycle during alternate cycles while in Group II ( $N=8)$ mares were flushed twice in a cycle for 2 contiguous cycles. Total protein concentrations and total recoverable protein of uterine flushings taken on Day 3 of oestrus and Day 8 after ovulation in each of the 2 groups and between the 2 groups did not differ significantly. The length of oestrus and dioestrus was not affected by the flushing procedures. Total recoverable protein and total protein concentrations of flushings were higher at Day 3 of oestrus and Day 8 and 15 after ovulation $(P<0.01)$ when a micro-organism was isolated from the uterus before flushing.
\end{abstract}

\section{Introduction}

During oestrus, the mare cervix is relaxed, providing a direct route for micro-organisms to be carried into the uterus at coitus (Millar, 1952). The uterus at this time not only must move spermatozoa towards the oviduct but must also support sperm survival and eliminate microorganisms so that the environment is suitable for the spermatozoa as well as for the developing embryo.

Information is scanty concerning mare uterine control of microbial growth or the concommitant uterine secretory changes induced by uterine micro-organisms. Six of the 10 known equine immunoglobulins have been found in mare uterine flushings (Kenney \& Khaleel, 1975) and levels of some of these immunoglobulins appear to be higher in fertile than in sub-fertile mares (Asbury, Halliwell, Foster \& Longino, 1980; Mitchell, Liu, Perryman, Stabenfeldt \& Hughes, 1982). Flushings from infected mare uteri also have significantly higher total protein concentrations than do those from uteri not harbouring bacteria (Blue, Brady, Davidson, \& Kenney, 1982). The influence of micro-organisms that do not infect the uterus on uterine protein levels has not been determined.

Reports of mare uterine secretory activity in relation to the oestrous cycle are at variance: secretory rates are higher at dioestrus (Zavy, Bazer \& Sharp, 1978) or are not different in horse mares (Blue et al., 1982) or pony mares (Zavy et al., 1982). One difference is the frequency of collection: flushings were taken by Blue et al. (1982) twice in a cycle whereas Zavy et al. (1978) obtained one flushing in a cycle.

The objective of the present studies of mare uterine resistance to bacteria was to determine whether protein content of uterine fluid is affected by frequency of flushing, presence of microorganisms in the uterus before flushing or stage of cycle. 


\section{Materials and Methods}

Mixed-breed mares with an average age of 10 years were used. The 20 mares were maintained on pasture with a daily grain ration and were selected on the basis of having a palpably normal genital tract, a Category I or II endometrium (Kenney, 1978) and an endometrial swab culture at the time of examination which gave no bacterial growth. The mares were individually teased with a stallion daily for signs of oestrus. Ovulation was confirmed by palpation per rectum. The day of ovulation was termed Day 1 after ovulation.

\section{Flushing procedure}

Mares were confined in stocks with their tails enclosed in plastic bags. The vulva and perineal area were alternately scrubbed and rinsed three times using a povidone-iodine solution (Betadine: Purdue Frederick Co. CT 06856, U.S.A.). A double-guarded swab was passed into the uterine lumen (Blanchard, Garcia, Hurtgen \& Kenney, 1981) and subsequently streaked on a $5 \%$ sheep blood agar plate. Microbial growth was assessed after aerobic incubation for $48 \mathrm{~h}$ at $37^{\circ} \mathrm{C}$. An endometrial swabbing was considered positive if 2 or more similar colonies were isolated on the streak. When an organism was isolated, the endometrium was reswabbed 3-6 days later and results compared. After swabbing the endometrium, the tip of a modified Foley catheter was immediately placed into the uterine lumen. The cuff was filled with approximately $100 \mathrm{cc}$ of air to seal the internal os of the cervix. Sterile saline, $50 \mathrm{ml} 0.9 \%(\mathrm{w} / \mathrm{v}) \mathrm{NaCl}$, was then infused into the uterine lumen and allowed to equilibrate for $2 \mathrm{~min}$. Fluid was collected aseptically by gravity into a sterile $50-\mathrm{ml}$ plastic centrifuge tube (Falcon). Procaine penicillin $\left(3 \times 10^{6}\right.$ units, Squibb) or neomycin sulphate ( $2 \mathrm{~g}$, Professional Veterinary Laboratories) in $60 \mathrm{ml}$ sterile saline were then infused into the uterine lumen. The flushings were centrifuged initially for $20 \mathrm{~min}$ at $600-1000 \mathrm{~g}$. The supernatant was centrifuged again at $4^{\circ} \mathrm{C}$ for $50 \mathrm{~min}$ at $10000 \mathrm{~g}$. The flushings were frozen in aliquots at $-20^{\circ} \mathrm{C}$ until assay.

\section{Flushing intervals}

All mares were allowed to undergo one oestrous cycle to establish that they had normal cyclic behaviour. Flushings were taken either once (Group I) or twice (Group II) within an oestrous cycle. For mares flushed once in a cycle, flushings were collected during alternate oestrous cycles on Day 3 of oestrus or Day 4, 6, 8, 10 or 15 after ovulation. When two flushings were taken within an oestrous cycle, one flushing was taken on Day 3 of oestrus and the other on Day 8 after ovulation during contiguous cycles. Flushings were also taken from anoestrous mares in January and early February (Group A). The presence of small, inactive ovaries, a flaccid cervix and lack of oestrous behaviour for 3 weeks were the criteria used to identify anoestrus.

\section{Protein analysis}

Total protein concentration was determined by the method of Lowry, Rosebrough, Farr \& Randall (1951) using bovine serum albumin (Sigma, St. Louis, MO, U.S.A.) as a standard. Differences in total protein concentration and total recoverable protein (total protein concentration $\times$ volume of flushing fluid recovered) due to sampling frequency were analysed as 2 $\times 2$ factorials using two levels of frequency and two stages of cycle. Total recoverable protein and total protein concentration of flushings recovered at Day 3 of oestrus, Days 8 and 15 after ovulation and during anoestrus were analysed by one-way analysis of variance. The effect of micro-organisms on total protein concentration and total recoverable protein was analysed as $2 \times 3$ factorials with a no-growth and a positive growth status of the uterus as the first factor and three stages of the cycle as the second factor (Steel \& Torrie, 1960). 


\section{Results}

Recovery of fluid infused into the uterine lumen averaged $76 \%$ (Table 1 ). No statistical difference was found for recovery at different stages of the cycle, or in relation to the presence of microorganisms or frequency of flushing. Considerable variation in recovery occurred for flushings taken at oestrus. Part of this variation was due to a failure of the catheter cuff to prevent fluid leakage through a relaxed cervix. On the other hand, recoveries have also reached $150 \%$ at oestrus.

Table 1. Comparison of $(\%)$ uterine fluid recovery from mares according to whether uterine swab cultures were positive or negative

\begin{tabular}{lccc}
\hline Stage of cycle & $\begin{array}{c}\text { Positive/negative } \\
\text { swab }\end{array}$ & $\begin{array}{c}\text { No. of } \\
\text { samples }\end{array}$ & $\begin{array}{c}\text { \% recovery* } \\
\text { (mean } \pm \text { s.e.m.) }\end{array}$ \\
\hline Day 3 of oestrus & - & 18 & $68 \cdot 8 \pm 8 \cdot 0$ \\
Dioestrus & + & 7 & $86 \cdot 3 \pm 13 \cdot 5$ \\
Anoestrus & - & 24 & $83 \cdot 1 \pm 3 \cdot 4$ \\
\multirow{2}{*}{ Total } & + & 5 & $80 \cdot 8 \pm 4 \cdot 5$ \\
& - & 4 & $58 \cdot 0 \pm 17 \cdot 7$ \\
\end{tabular}

*(Volume collected/volume infused $) \times 100$.

Flushing did not affect the length of oestrus or dioestrus. The length of dioestrus in cycles before flushing $(n=28)$ was $16.25 \pm 0.56$ (s.d.) days while the length of oestrus was $5.57 \pm 0.39$ days. For mares in Groups I and II dioestrus continued for 17.00 \pm 0.72 days $(n=22)$ and $17.44 \pm 1.26$ days $(n=9)$ respectively while oestrus lasted for $5.86 \pm 0.45$ and $6.22 \pm 0.46$ days respectively.

Total recoverable protein and total protein concentration of flushings taken from uteri with no bacterial growth before flushing are shown in Table 2 . The levels of total protein concentrations and of total recoverable protein in flushings taken on Day 8 after ovulation from Group I mares, although higher, were not significantly different from values at Day 3 of oestrus or at Day 8 after ovulation in Group II mares. Pooled values for Day 3 of oestrus and for Day 8 after ovulation were

Table 2. Total protein concentrations and total recoverable protein in uterine flushings from mares which had negative or positive uterine swabs

\begin{tabular}{|c|c|c|c|c|c|c|c|}
\hline \multirow[b]{2}{*}{ Group } & \multirow[b]{2}{*}{ Stage of cycle } & \multicolumn{3}{|c|}{ Negative swabs } & \multicolumn{3}{|c|}{ Positive swabs } \\
\hline & & $\begin{array}{c}\text { No. of } \\
\text { samples }\end{array}$ & $\begin{array}{c}\text { Total protein } \\
(\mu \mathrm{g} / \mathrm{ml})\end{array}$ & $\begin{array}{l}\text { Total recoverable } \\
\text { protein }(\mathrm{mg})\end{array}$ & $\begin{array}{l}\text { No. of } \\
\text { samples }\end{array}$ & $\begin{array}{l}\text { Total protein } \\
\qquad(\mu \mathrm{g} / \mathrm{ml})\end{array}$ & $\begin{array}{l}\text { Total recoverable } \\
\text { protein }(\mathrm{mg})\end{array}$ \\
\hline I & $\begin{array}{l}\text { Day } 3 \text { of oestrus } \\
\text { Day } 4 \dagger \\
\text { Day } 6 \dagger \\
\text { Day } 8 \dagger \\
\text { Day } 10 \dagger \\
\text { Day } 15 \dagger\end{array}$ & $\begin{array}{l}8 \\
1 \\
1 \\
7 \\
7 \\
1 \\
4\end{array}$ & $\begin{array}{l}458 \cdot 74 \pm 47 \cdot 66 \\
219 \cdot 65 \\
446 \cdot 05 \\
889 \cdot 80 \pm 303.94 \\
427.92 \\
629 \cdot 34 \pm 86.83\end{array}$ & $\begin{array}{l}15.40 \pm 0.99 \\
10.54 \\
21 \cdot 41 \\
32.00 \pm 14.84 \\
17.54 \\
29.08 \pm 3.98\end{array}$ & 2 & $2982 \cdot 30 \pm 109 \cdot 50^{*}$ & $120 \cdot 18 \pm 11.97^{*}$ \\
\hline II & $\begin{array}{l}\text { Day } 3 \text { of oestrus } \\
\text { Day } 8 \dagger\end{array}$ & $\begin{array}{r}9 \\
12\end{array}$ & $\begin{array}{l}487 \cdot 36 \pm 66 \cdot 89 \\
720 \cdot 32 \pm 156.06\end{array}$ & $\begin{array}{l}17.91 \pm 3.52 \\
27.63 \pm 7.50\end{array}$ & & & \\
\hline A & Anoestrus & 4 & $838.41 \pm 383.36$ & $15 \cdot 28 \pm 4.08$ & 1 & 1859.00 & $29 \cdot 74$ \\
\hline $\mathrm{I}+\mathrm{II}$ & Day 3 of oestrus & 17 & $473.89 \pm 40 \cdot 80$ & $16.73 \pm 1.89$ & 7 & $1840 \cdot 38 \pm 1042 \cdot 86^{*}$ & $63 \cdot 46 \pm 27 \cdot 14^{*}$ \\
\hline $\mathrm{I}+\mathrm{II}$ & Day $8 \dagger$ & 19 & $782 \cdot 76 \pm 145 \cdot 31$ & $28.91 \pm 6.62$ & 3 & $1323 \cdot 38 \pm 413 \cdot 29^{*}$ & $52.74 \pm 17.05^{*}$ \\
\hline
\end{tabular}

Values are mean \pm s.e.m.

* Significantly different from values for negative mares, $P<0 \cdot 01$.

+ After ovulation. 
therefore used for further statistical comparisons. The values for Group I mares on Day 15 after ovulation and Group A mares were not significantly different from those for Day 3 of oestrus and Day 8 after ovulation (Groups I \& II, Table 2). The flushings taken at Day 4, 6 or 10 after ovulation in Group I mares also had total protein values within the range found for Day 3 of oestrus and Day 8 after ovulation.

When micro-organisms were recovered from the uterus before flushing, total protein concentration and total recoverable protein levels increased (Table 2). Mean values at Day 3 of oestrus and Days 8 and 15 after ovulation were significantly higher $(P<0.01)$ than mean values when the uterus was not harbouring an organism.

Most flushings appeared clear at recovery without a noticeable difference in pellet size after centrifugation. However, considerable variation in total protein concentrations was noticed, especially in flushings taken on Day 3 of oestrus. When the individual total protein concentrations were examined and compared with those in Table 2, values were not always elevated when an organism had been isolated before flushing (Table 3). For example, Aspergillus sp. was not associated with a dramatic increase in total protein concentration or total recoverable protein levels, as was seen with Pseudomonas aeruginosa or Staphylococcus sp. With the exception of Escherichia coli, uterine residence of these micro-organisms was short-lived because they were not recovered when the uterus was re-swabbed 3-6 days later. The uterus from which $E$. coli was isolated was treated with antibiotics to ensure immediate recovery for another series of experiments. A vulvar discharge was not detected with any of the isolations.

Table 3. Total recoverable protein and total protein concentration in uterine flushings after recovery of specific micro-organisms from the uteri of mares

\begin{tabular}{|c|c|c|c|}
\hline $\begin{array}{c}\text { Stage of cycle when } \\
\text { flushed }\end{array}$ & Micro-organism & $\begin{array}{l}\text { Total } \\
\text { protein } \\
(\mu \mathrm{g} / \mathrm{ml})\end{array}$ & $\begin{array}{l}\text { Total } \\
\text { recoverable } \\
\text { protein (mg) }\end{array}$ \\
\hline Day 3 of oestrus & $\begin{array}{l}\text { Aspergillus sp. } \\
\text { Staphylococcus sp. } \\
\text { Pseudomonas aeruginosa } \\
\text { B-Haemolytic streptococcus } \\
\text { Mucor sp. }\end{array}$ & $\begin{array}{r}1073 \cdot 6 \\
680 \cdot 4 \\
574 \cdot 0 \\
1446 \cdot 8 \\
508 \cdot 5 \\
550 \cdot 1 \\
8049 \cdot 0\end{array}$ & $\begin{array}{r}30 \cdot 06 \\
29 \cdot 26 \\
28 \cdot 70 \\
108 \cdot 51 \\
10 \cdot 17 \\
19 \cdot 80 \\
402 \cdot 45\end{array}$ \\
\hline Day 8 after ovulation & $\begin{array}{l}\text { Aspergillus sp. } \\
\text { Pseudomonas aeruginosa } \\
\text { Escherichia coli }\end{array}$ & $\begin{array}{l}519 \cdot 0 \\
1561 \cdot 0 \\
1890 \cdot 20\end{array}$ & $\begin{array}{l}22 \cdot 31 \\
54 \cdot 64 \\
81 \cdot 28\end{array}$ \\
\hline Day 15 after ovulation & $\begin{array}{l}\text { Staphylococcus sp. } \\
\text { Not identified }\end{array}$ & $\begin{array}{l}2872 \cdot 8 \\
3091 \cdot 8\end{array}$ & $\begin{array}{l}132 \cdot 15 \\
108 \cdot 21\end{array}$ \\
\hline Anoestrus & $\beta$-Haemolytic streptococcus & $1859 \cdot 0$ & $29 \cdot 74$ \\
\hline
\end{tabular}

\section{Discussion}

Total protein concentration and total recoverable protein levels in mare uterine flushings taken singly on Day 8 after ovulation in alternate cycles were elevated but not significantly higher than values obtained on Day 8 after ovulation for flushings taken as one of two flushings in successive cycles. Evidently the interval chosen for flushing in successive cycles is ample for the maintenance of uterine protein levels. A significant rise of protein levels in flushings taken during alternate cycles would indicate a slow replacement of uterine luminal proteins by the mare.

The technique of flushing, by its limitations, can only estimate uterine fluid content (Heap, 1962). The rise in protein content of uterine flushings at mid-and late dioestrus found by Zavy et al. (1978) indicates increased uterine secretory activity during dioestrus. However, in this study and in 
the work of Blue et al. (1982), no significant rise in uterine fluid protein was found during dioestrus. This discrepancy may be resolved by examination of flushing constituents. An increase in uterine total protein concentration would be expected if there was an inflammatory reaction to a microorganism due to mobilization of white blood cells and increased vascular permeability (Hawk, Brinsfield \& Righter, 1963). Low protein values associated with some positive swab cultures in this study may be due to uterine drainage through a relaxed cervix under the influence of oestrogen (Black, Simon, Kidder \& Wiltbank, 1954). Low values may also indicate a contaminant picked up from the lower reproductive tract. The use of a double guarded swab greatly reduces this possibility (Blanchard et al., 1981) but does not abolish it. The micro-organisms recovered in this study may also have been transitory in nature. The uterus is prone to invasion of bacteria from the lower reproductive tract. Observations of women (Bollinger, 1964) and mares (Scott, Daley, Baird, Sturgess \& Frost, 1971; Newcombe, 1978) have indicated a transient population of microbes in the uterus. Positive swab cultures of the uterus have been recovered with an absence of uterine inflammation viewed histologically (Williamson, Dunning, O'Connor \& Penhale, 1983). Therefore, low total protein values, may indicate little reaction to the isolated organism while micro-organisms penetrating the mucosal barrier may activate the second line of defence (Brandtzaeg, 1973) with a resultant increase in total protein concentration of the flushings.

At no time in this study was a cycle significantly shortened due to flushing. This is in agreement with the work of others (Zavy et al., 1978) in that trauma to the uterus is minimal compared to infusion of large volumes of saline (Arthur, 1975). Uterine biopsy or cervical dilatation has been shown to shorten the mare oestrous cycle (Hurtgen \& Ganjam, 1979). To investigate whether the corpus luteum may be influenced by flushing, plasma samples were taken from two mares after flushing on Day 8 after ovulation. Progesterone levels from these samples were compared to progesterone levels $24 \mathrm{~h}$ later: on Day 8 the values were 14.5 and $13.3 \mathrm{ng} / \mathrm{ml}$ and on Day 9 they were 15.5 and $15.4 \mathrm{ng} / \mathrm{ml}$ respectively. These results suggest that corpus luteum function has not been altered by the flushing procedure. Failure to shorten the cycle in this study may have been due to lack of cervical and uterine stimulation during flushing or removal of the responsible mediator (e.g. prostaglandin) with the flushing.

The support of Hempt Farms, Wycombe House Stud, Mrs. A. C. Riggs and the Standardbred Breeders and Owners Association of New Jersey, Inc. is acknowledged. We thank Mrs Marge Cummings for assistance with the microbiology and Mr G. Dreisbach for excellent care of the animals.

\section{References}

Arthur, G.H. (1975) Influence of intrauterine saline infusion upon the oestrous cycle of the mare. $J$. Reprod. Fert., Suppl. 23, 231-234.

Asbury, A.C., Halliwell, R.E.W., Foster, G.W. \& Longino, S.J. (1980) Immunoglobulins in uterine secretions of mares with differing resistance to endometritis. Theriogenology 14, 299-308.

Black, W.G., Simon, J., Kidder, H.E. \& Wiltbank, J.N. (1954) Bactericidal activity of the uterus in the rabbit and the cow. Am. J. vet. Res. 15, 247-251.

Blanchard, T.L., Garcia, M.C., Hurtgen, J.P. \& Kenney, R.M. (1981) Comparison of two techniques for obtaining endometrial bacteriologic cultures in the mare. Theriogenology 16, 85-93.

Blue, M.G., Brady, A.A., Davidson, J.N. \& Kenney, R.M. (1982) Studies on the composition and antibacterial activity of uterine fluid from mares. J. Reprod. Fert., Suppl. 32, 143-149.
Bollinger, C.C. (1964) Bacterial flora of the non-pregnant uterus: a new culture technic. Obstet. Gynec., N.Y. 23, 251-255.

Brandtzaeg, P. (1973) Structure, synthesis and external transfer of mucosal immunoglobulins. Annls Inst. Pasteur Paris 124C, 417-438.

Hawk, H.W., Brinsfield, T.H. \& Righter, H.F. (1963) Control by ovarian hormones of vascular permeability in normal and experimentally-infected sheep uteri. J. Reprod. Fert. 6, 71-77.

Heap, R.B. (1962) Some chemical constituents of uterine washings: a method of analysis with results from various species. $J$. Endocr. 24, 367-378.

Hurtgen, J.P. \& Ganjam, V.K. (1979) The effect of intrauterine and cervical manipulation on the equine oestrous cycle and hormone profiles. J. Reprod. Fert., Suppl. 27, 191-197. 
Kenney, R.M. (1978) Cyclic and pathological changes of the mare endometrium as detected by biopsy with a note on early embryonic death. J. Am. vet. med. Ass. 172, 241-262.

Kenney, R.M. \& Khaleel, S.A. (1975) Bacteriostatic activity of the mare uterus: a progress report on immunoglobulins. J. Reprod. Fert., Suppl. 23, 357358.

Lowry, O.H., Rosebrough, N.J., Farr, A.L. \& Randall, R.J. (1951) Protein measurement with the folin phenol reagent. J. biol. Chem. 193, 265-275.

Millar, R. (1952) Forces observed during coitus in the Thoroughbred. Aust. vet. J. 28, 127-128.

Mitchell, G., Liu, I.K.M., Perryman, L.E., Stabenfeldt, G.H. \& Hughes, J.P. (1982) Preferential production and secretion of immunoglobulins by the equine endometrium - a mucosal immune system. $J$. Reprod. Fert., Suppl. 32, 161-168.

Newcombe, J.R. (1978) Comparison of the bacterial flora of three sites in the genital tract of the mare. Vet. Rec. 102, 169-170.
Scott, P., Daley, P., Baird, G.G., Sturgess, S. \& Frost, A.J. (1971) The aerobic bacterial flora of the reproductive tract of the mare. Vet. Rec. 88, 58-61.

Steel, R. \& Torrie, J. (1960) Principles and Procedures of Statistics. McGraw-Hill, New York.

Williamson, P., Dunning, A., O'Connor, J. \& Penhale, W.J. (1983) Immunoglobulin levels, protein concentrations and alkaline phosphatase activity in uterine flushings from mares with endometritis. Theriogeno$\log y 19,441-445$.

Zavy, M.T., Bazer, F.W. \& Sharp, D.C. (1978) Uterine luminal protein in the cycling mare. J. Anim. Sci. 47, 672-676.

Zavy, M.T., Sharp, D.C., Bazer, F.W., Fazleabas, A., Sessions, F. \& Roberts, R.M. (1982) Identification of stage-specific and hormonally induced polypeptides in the uterine protein secretions of the mare during the oestrous cycle and pregnancy. J. Reprod. Fert. 64, 199-207.

Received 29 June 1983 